\title{
Metabolism of Clomeprop in Plant Seedlings
}

\author{
Chalermchai WONGWATTANA and Kozo ISHIZUKA
}

Institute of Applied Biochemistry, Tsukuba University, Tsukuba-shi, Ibaraki 305, JAPAN.

Clomeprop (2- (2,4-dichloro-3-methylphenoxy) propionanilide or MY-15), a selective rice herbicide which is abbreviated here as CMP, was reported to be effective for many species of broadleaf and cyperus weeds. Both clomeprop and its acid metabolite (2- (2, 4-dichloro-3-methylphenoxy) propionic acid), abbreviated DMPA, were reported to exhibit herbicidal activity ${ }^{3,4}$. Clomeprop in plants might be metabolized to DMPA, the herbicidal active compound, and the herbicidal activity of this herbicide was provided from the metabolite DMPA, similar to the case of naproanilide ${ }^{2,5)}$.<smiles>Cc1c(Cl)ccc(OCC(C)C(=O)Nc2ccccc2)c1Cl</smiles>

Clomeprop, CMP<smiles>Cc1c(Cl)ccc(OCC(C)C(=O)O)c1Cl</smiles>

DMPA

From the previous study, it was found that azuki bean and rice seedlings were tolerant to clomeprop and DMPA, whereas tomato and radish seedlings were susceptible ${ }^{6}$. In order to clarify the mechanism of selectivity of clomeprop in plants, metabolism study of this herbicide and its acid metabolite was conducted in four species of plants : azuki bean, rice, tomato and radish.

\section{Materials and Methods}

\section{Plant materials}

Seedlings of azuki bean (Azukia angularis), rice (Oryza sativa L. cv. Nihonbare), tomato (Lycopersicon esculentum MILL.) and radish (Raphanus sativus L.) were prepared as described in the previous study ${ }^{6}$. Rice seedlings at the 3-leaf-stage of growth and 7-day-old seedlings of azuki bean, tomato and radish were used in this study.

\section{${ }^{14} \mathrm{C}$ herbicide solutions}

Solutions used were ${ }^{14} \mathrm{C}-\mathrm{CMP}$ and ${ }^{14} \mathrm{C}$ DMPA (bezene rings in the phenoxy moieties are labeled with ${ }^{14} \mathrm{C}$, specific activity 13.5 and $17.6 \mu \mathrm{Ci} / \mathrm{mg}$, respectively) at the concentration of $10^{-5} \mathrm{M}$ dissolved in $1 \%$ acetone and 750ppm Tween 20.

\section{Application method}

Roots of the seedlings were immersed in the test solutions to $1 \mathrm{~cm}$ below the base of stems for $24 \mathrm{hr}$, then washed with distilled water. Thereafter, plants were transferred to herbicide-free nutrient solutions.

\section{Metabolism study}

Plants were harvested 0,1 and 3 days after soaking and shoots separated from roots. The fresh weight, of each part was determined and amounts of the parent compound and its metabolites were investigated following the steps shown in Fig.1.

Plant samples were homogenized twice in an acetone/water solution ( $2 / 1$ by volume) and filtered through a membrane filter. Radioactivity of acetone/water-insoluble fractions in residues was quantified by combustion. Acetone in acetone/water extracts was evaporated, and the remainder of the aqueous solutions was then extracted twice with dichloromethane at $\mathrm{pH}$ below 2 in order to obtain the dichloromethane- and water-soluble fractions. Radioactivity in each

* Parts of this work were reported at the $27^{\text {th }}$ annual meeting of the Weed Science Society of Japan in April, 1988. 


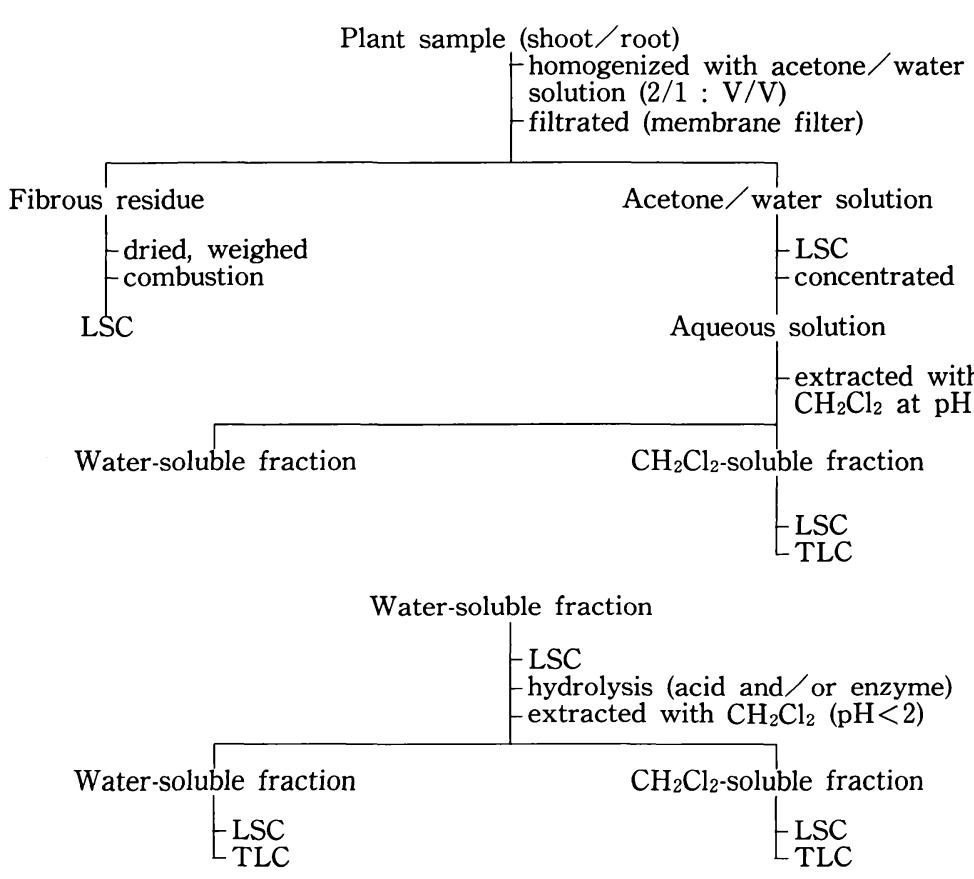

Fig. 1. Flow chart of metabolism study of clomeprop

fraction (acetone/water-insoluble, water soluble and dichloromethane-soluble fractions) was determined using a liquid scintillation spectrometer (Beckman LS 8100).

The parent compound and metabolites in dichloromethane fractions were identified and quantified by thin layer chromatography.

In order to identify metabolites in the water-soluble fraction, these fractions were hydrolyzed by either $\mathrm{HCl}$ or $\beta$-glucosidase and the hydrolyzed compounds were extracted and studied by the same method as described above.

For thin layer chromatography study, the pre-coated aluminum TLC plate with concentrated zone (Merck Art 5583) was used for the dichloromethane-soluble fraction, and the developing solution was benzene: methanol : acetic acid ( $100: 5: 15$ by volume)

\section{Results and Discussion}

All plant species tested in this experiment metabolized ${ }^{14} \mathrm{C}-\mathrm{CMP}$ and ${ }^{14} \mathrm{C}$-DMPA to water-soluble and acetone/water-insoluble metabolites, but differed in the rates of metabolism.

Azuki bean and rice effectively metabolized ${ }^{14} \mathrm{C}-\mathrm{CMP}$ and ${ }^{14} \mathrm{C}$-DMPA in both shoot and root. Three days after application, detected radioactivity in dichloromethanesoluble fraction (which contained the parent compound and DMPA) in shoot and root was 33 and $40 \%$ respectively in ${ }^{14} \mathrm{C}$-CMP treatment and 3 and $5 \%$ respectively in ${ }^{14} \mathrm{C}-$ DMPA treatment in azuki bean; and 30 and $27 \%$ in ${ }^{14} \mathrm{C}-\mathrm{CMP}$ treatment and 19 and $9 \%$ in ${ }^{14} \mathrm{C}$-DMPA treatment in rice (Fig. 2 and 3 ).

In tomato and radish, the percents of radioactivity remaining in the dichloromethane fraction were larger than those in azuki bean and rice (Fig. 2 and 3). In tomato 38\% was found in shoots and $76 \%$ in roots with ${ }^{14} \mathrm{C}$-CMP treatment and $15 \%$ and $10 \%$ respectively with ${ }^{14} \mathrm{C}$-DMPA treatment. In radish $72 \%$ was found in shoots and $91 \%$ in roots with ${ }^{14} \mathrm{C}$-CMP treatment, and 30 and $16 \%$ 


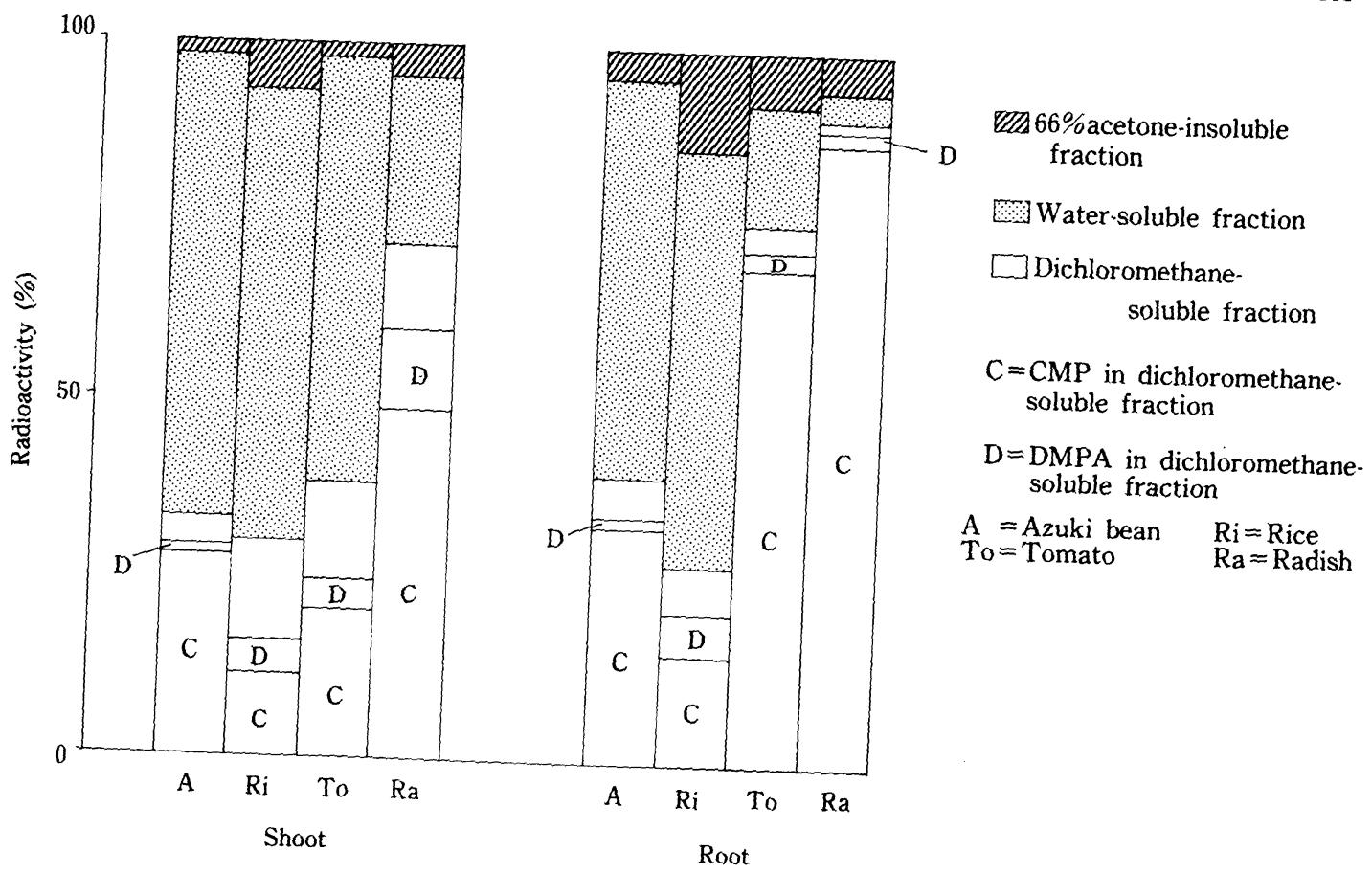
Fig. 2. Distribution of ${ }^{14} \mathrm{C}$ derived from ${ }^{14} \mathrm{C}-\mathrm{CMP}$ into each fraction
3 days after application.

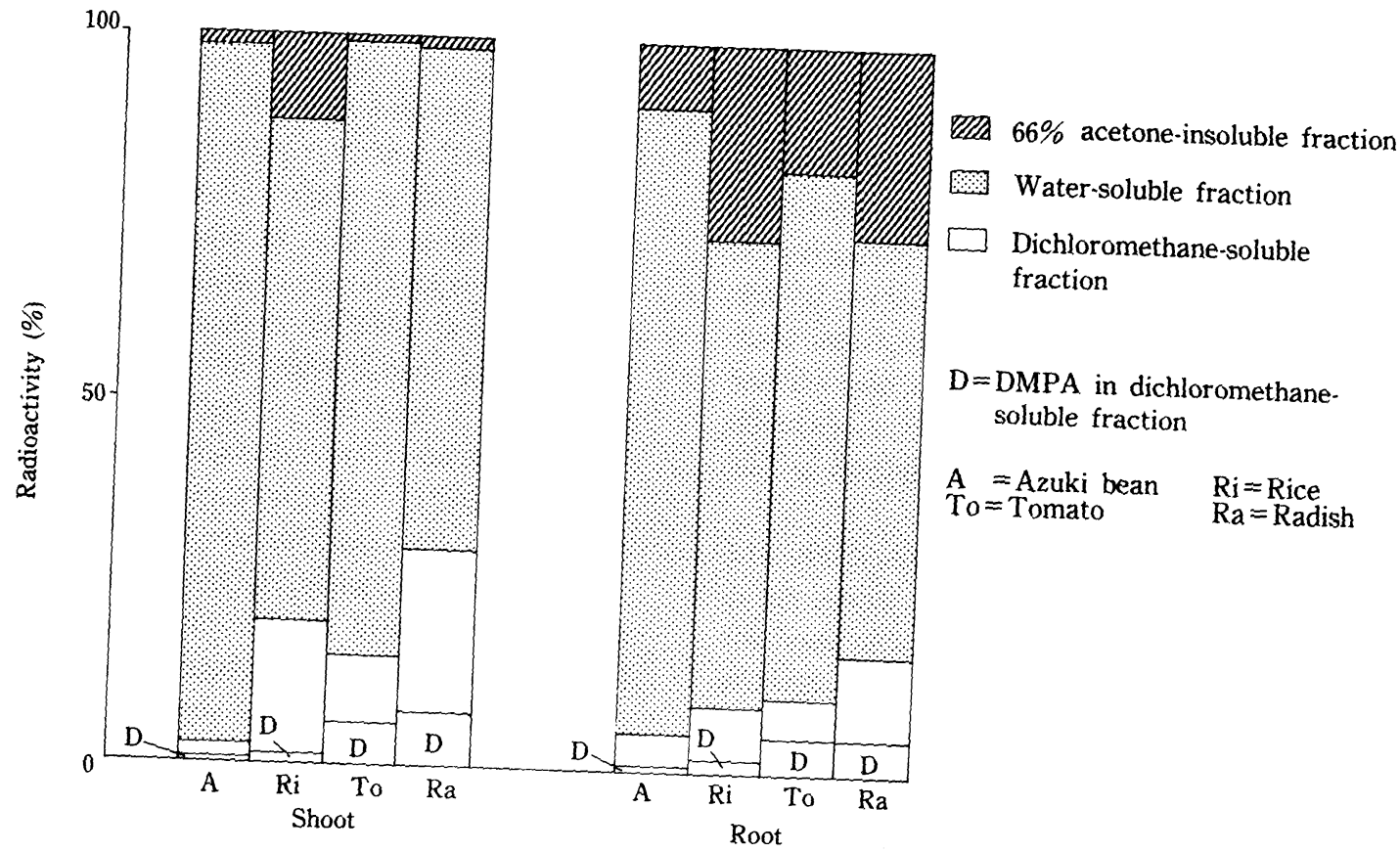

Fig. 3. Distribution of ${ }^{14} \mathrm{C}$ derived from ${ }^{14} \mathrm{C}$-DMPA into each fraction 3 days after application. 
Table 1. Percent of parent compounds and metabolites in $\mathrm{CH}_{2} \mathrm{Cl}_{2}$-soluble fraction derived from root applied ${ }^{14} \mathrm{C}-\mathrm{CMP}$ and ${ }^{14} \mathrm{C}$-DMPA in roots and shoots of azuki bean seedlings.

\begin{tabular}{|c|c|c|c|c|c|c|c|c|}
\hline & \multicolumn{6}{|c|}{$\%^{1)}$ of radioactivity } \\
\hline $\begin{array}{l}\text { Plant } \\
\text { parts }\end{array}$ & $\begin{array}{c}\text { Compounds } \\
\text { treated }\end{array}$ & $\mathrm{DAA}^{2)}$ & CMP & DMPA & $\begin{array}{c}\text { 3- } \mathrm{CH}_{2} \mathrm{OH} \\
\text { DMPA }\end{array}$ & $\mathrm{UK}^{3)}$ & Origin & Total \\
\hline \multirow{6}{*}{ Root } & & 0 & 92.80 & 0.91 & 0.17 & 1.28 & 0.14 & 95.30 \\
\hline & ${ }^{14} \mathrm{C}-\mathrm{CMP}$ & 1 & 82.00 & 1.07 & 0.12 & 1.34 & 0.37 & 84.90 \\
\hline & & 3 & 32.43 & 1.77 & 0.57 & 3.08 & 1.75 & 39.60 \\
\hline & & 0 & - & 12.62 & 3.39 & 4.60 & 1.79 & 22.40 \\
\hline & ${ }^{14} \mathrm{C}$-DMPA & 1 & - & 1.87 & 0.37 & 2.69 & 1.67 & 6.60 \\
\hline & & 3 & - & 1.07 & 0.35 & 2.32 & 1.56 & 5.30 \\
\hline \multirow{6}{*}{ Shoot } & & 0 & 60.13 & 1.26 & 1.04 & 2.33 & 1.84 & 66.60 \\
\hline & ${ }^{14} \mathrm{C}-\mathrm{CMP}$ & 1 & 38.51 & 1.34 & 1.17 & 1.25 & 2.33 & 44.60 \\
\hline & & 3 & 28.13 & 0.95 & 0.94 & 1.42 & 1.46 & 32.90 \\
\hline & & 0 & - & 0.89 & 2.71 & 3.37 & 1.23 & 8.20 \\
\hline & ${ }^{14} \mathrm{C}$-DMPA & 1 & - & 0.63 & 1.14 & 0.92 & 0.71 & 3.40 \\
\hline & & 3 & - & 0.30 & 1.15 & 0.59 & 0.66 & 2.70 \\
\hline
\end{tabular}

1 based on total radioactivity in either roots or shoots

2 DAA : days after application

3 consists of several unidentified metabolites

respectively with ${ }^{14} \mathrm{C}$-DMPA treatment 3 days after application (Fig. 2 and 3 ).

Tables 1 to 4 show the percents of parent compounds and their metabolites in dichloromethane fraction with both ${ }^{14} \mathrm{C}-\mathrm{CMP}$ and ${ }^{14} \mathrm{C}$-DMPA treatments incorporated by azuki bean, rice, tomato and radish, respectively. In both shoot and root, the main metabolites derived from ${ }^{14} \mathrm{C}-\mathrm{CMP}$ were identified as DMPA and $3-\mathrm{CH}_{2} \mathrm{OH}-\mathrm{DMPA}$ (2-(2,4-dichloro-3-hydroxymethylphenoxy) propionic acid), and from ${ }^{14} \mathrm{C}$-DMPA was identified as

Table 2. Percent of parent compounds and metabolites in $\mathrm{CH}_{2} \mathrm{Cl}_{2}$-soluble fraction derived from root applied ${ }^{14} \mathrm{C}-\mathrm{CMP}$ and ${ }^{14} \mathrm{C}$-DMPA in roots and shoots of rice seedlings.

\begin{tabular}{|c|c|c|c|c|c|c|c|c|}
\hline \multirow[b]{2}{*}{$\begin{array}{l}\text { Plant } \\
\text { parts }\end{array}$} & \multirow[b]{2}{*}{$\begin{array}{c}\text { Compounds } \\
\text { treated }\end{array}$} & \multirow[b]{2}{*}{$\mathrm{DAA}^{2)}$} & \multicolumn{6}{|c|}{$\%^{1)}$ of radioactivity } \\
\hline & & & CMP & DMPA & $\begin{array}{c}3-\mathrm{CH}_{2} \mathrm{OH} \\
\text { DMPA }\end{array}$ & $\mathrm{UK}^{3)}$ & Origin & Total \\
\hline \multirow{6}{*}{ Root } & & 0 & 84.09 & 1.84 & 0.55 & 3.58 & 1.84 & 91.90 \\
\hline & ${ }^{14} \mathrm{C}-\mathrm{CMP}$ & 1 & 67.80 & 4.25 & 1.22 & 2.05 & 0.61 & 75.94 \\
\hline & & 3 & 14.69 & 6.04 & 3.56 & 1.64 & 1.42 & 27.35 \\
\hline & & 0 & - & 12.66 & 6.24 & 3.75 & 1.37 & 24.02 \\
\hline & ${ }^{14} \mathrm{C}$-DMPA & 1 & - & 3.08 & 5.17 & 2.33 & 1.56 & 12.14 \\
\hline & & 3 & - & 1.57 & 4.79 & 1.61 & 1.37 & 9.34 \\
\hline \multirow{6}{*}{ Shoot } & & 0 & 63.64 & 5.13 & 2.19 & 5.98 & 7.24 & 84.18 \\
\hline & ${ }^{14} \mathrm{C}-\mathrm{CMP}$ & 1 & 25.02 & 3.55 & 4.88 & 11.13 & 15.57 & 60.15 \\
\hline & & 3 & 11.50 & 4.52 & 5.46 & 6.88 & 1.59 & 29.95 \\
\hline & & 0 & - & 16.57 & 15.13 & 3.14 & 5.14 & 39.98 \\
\hline & ${ }^{14} \mathrm{C}$-DMPA & 1 & - & 3.08 & 8.50 & 6.35 & 4.10 & 22.03 \\
\hline & & 3 & - & 1.19 & 7.39 & 5.46 & 5.33 & 19.36 \\
\hline
\end{tabular}

1 based on total radioactivity in either roots or shoots

2 DAA : days after application

3 consists of several unidentified metabolites 
Table 3. Percent of parent compounds and metabolites in $\mathrm{CH}_{2} \mathrm{Cl}_{2}$-soluble fraction derived from root applied ${ }^{14} \mathrm{C}-\mathrm{CMP}$ and ${ }^{14} \mathrm{C}$-DMPA in roots and shoots of tomato seedlings.

\begin{tabular}{|c|c|c|c|c|c|c|c|c|}
\hline & & & & & $\%^{1}$ of ra & activity & & \\
\hline $\begin{array}{l}\text { Plant } \\
\text { parts }\end{array}$ & $\begin{array}{c}\text { Compounds } \\
\text { treated }\end{array}$ & $\mathrm{DAA}^{2}$ & CMP & DMPA & $\begin{array}{c}3-\mathrm{CH}_{2} \mathrm{OH} \\
\text { DMPA }\end{array}$ & $\mathrm{UK}^{3}$ & Origin & Total \\
\hline \multirow{6}{*}{ Root } & \multirow{3}{*}{${ }^{14} \mathrm{C}-\mathrm{CMP}$} & 0 & 95.67 & 0.58 & 0.19 & 0.68 & 0.10 & 97.22 \\
\hline & & 1 & 90.68 & 1.09 & 0.48 & 0.65 & 0.13 & 93.03 \\
\hline & & 3 & 69.75 & 2.69 & 1.70 & 1.28 & 0.35 & 75.77 \\
\hline & \multirow{3}{*}{${ }^{14} \mathrm{C}$-DMPA } & 0 & - & 20.63 & 2.64 & 2.36 & 0.26 & 25.89 \\
\hline & & 1 & - & 3.27 & 2.22 & 1.86 & 0.16 & 7.51 \\
\hline & & 3 & - & 4.88 & 3.43 & 1.75 & 0.34 & 10.40 \\
\hline \multirow{6}{*}{ Shoot } & \multirow{3}{*}{${ }^{14} \mathrm{C}-\mathrm{CMP}$} & 0 & 58.15 & 7.16 & 4.34 & 1.51 & 1.16 & 72.32 \\
\hline & & 1 & 34.32 & 7.33 & 9.30 & 1.55 & 0.96 & 53.46 \\
\hline & & 3 & 20.65 & 4.16 & 11.08 & 1.15 & 1.42 & 38.46 \\
\hline & \multirow{3}{*}{${ }^{14} \mathrm{C}$-DMPA } & 0 & - & 15.25 & 3.50 & 2.53 & 0.70 & 21.98 \\
\hline & & 1 & - & 7.40 & 4.72 & 2.20 & 0.47 & 14.79 \\
\hline & & 3 & - & 5.63 & 6.62 & 1.42 & 1.17 & 14.84 \\
\hline
\end{tabular}

1 based on total radioactivity in either roots or shoots

2 DAA : days after application

3 consists of several unidentified metabolites

$3-\mathrm{CH}_{2} \mathrm{OH}$-DMPA in all 4 species although the amounts produced were different.

In azuki bean (Table 1), the amount of root absorbed ${ }^{14} \mathrm{C}$-CMP decreased rapidly in both roots and shoots. Three days after application there remained, respectively, only
32.43 and $28.13 \%$ of the total radioactivity. Only a small amount (less than 2\%) of the metabolites DMPA and 3- $\mathrm{CH}_{2} \mathrm{OH}-\mathrm{DMPA}$ derived from ${ }^{14} \mathrm{C}-\mathrm{CMP}$ was found in both plant parts. With ${ }^{14} \mathrm{C}-\mathrm{DMPA}$ treatment, the initial compound DMPA was metabolized

Table 4. Percent of parent compounds and metabolites in $\mathrm{CH}_{2} \mathrm{Cl}_{2}$-soluble fraction derived from root applied ${ }^{14} \mathrm{C}$-CMP and ${ }^{14} \mathrm{C}$-DMPA in roots and shoots of radish seedlings.

\begin{tabular}{|c|c|c|c|c|c|c|c|c|}
\hline & & & & & $\%^{1)}$ of $\mathrm{r}$ & oactivity & & \\
\hline $\begin{array}{l}\text { Plant } \\
\text { parts }\end{array}$ & $\begin{array}{c}\text { Compounds } \\
\text { treated }\end{array}$ & $\mathrm{DAA}^{2)}$ & CMP & DMPA & $\begin{array}{l}\text { 3- } \mathrm{CH}_{2} \mathrm{OH} \\
\text { DMPA }\end{array}$ & $U^{3)}$ & Origin & Total \\
\hline \multirow{6}{*}{ Root } & \multirow{3}{*}{${ }^{14} \mathrm{C}-\mathrm{CMP}$} & 0 & 97.58 & 0.43 & 0.06 & 0.55 & 0.04 & 98.66 \\
\hline & & 1 & 94.64 & 0.68 & 0.11 & 0.68 & 0.09 & 96.20 \\
\hline & & 3 & 87.70 & 1.81 & 0.39 & 1.26 & 0.27 & 91.43 \\
\hline & \multirow{3}{*}{${ }^{14} \mathrm{C}$-DMPA } & 0 & - & 20.91 & 7.86 & 10.57 & 1.18 & 40.52 \\
\hline & & 1 & - & 7.88 & 6.73 & 7.03 & 0.49 & 22.13 \\
\hline & & 3 & - & 5.04 & 6.25 & 4.31 & 0.55 & 16.15 \\
\hline \multirow{6}{*}{ Shoot } & \multirow{3}{*}{${ }^{14} \mathrm{C}-\mathrm{CMP}$} & 0 & 69.30 & 7.31 & 3.74 & 2.98 & 1.70 & 85.03 \\
\hline & & 1 & 60.03 & 10.35 & 4.30 & 3.18 & 1.75 & 79.61 \\
\hline & & 3 & 48.90 & 10.82 & 7.00 & 3.31 & 2.09 & 72.12 \\
\hline & \multirow{3}{*}{${ }^{14} \mathrm{C}$-DMPA } & 0 & - & 24.15 & 16.35 & 8.25 & 1.87 & 50.62 \\
\hline & & 1 & - & 10.87 & 19.93 & 7.54 & 0.90 & 39.24 \\
\hline & & 3 & - & 7.26 & 15.65 & 5.86 & 0.98 & 29.75 \\
\hline
\end{tabular}

1 based on total radioactivity in either roots or shoots

2 DAA : days after application

3 consists of several unidentified metabolites 
Table 5. Concentration of CMP and DMPA in roots and shoots of plant seedlings at various times after the root application of ${ }^{14} \mathrm{C}-\mathrm{CMP}$ or ${ }^{14} \mathrm{C}$-DMPA.

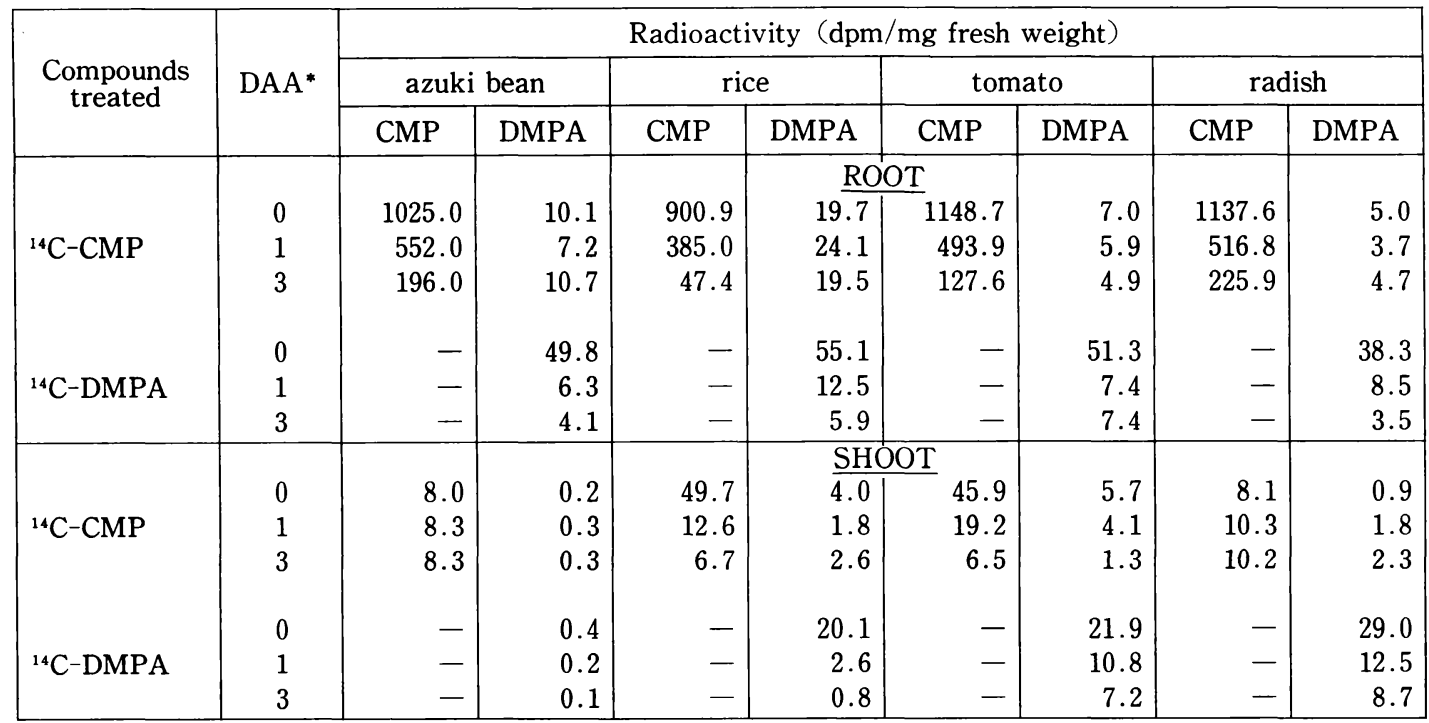

* DAA : days after application

rapidly, much more than CMP. Within 3 days, the remaining absorbed DMPA was only 1.07 and $0.30 \%$ in root and shoot, respectively. The metabolite $3-\mathrm{CH}_{2} \mathrm{OH}-\mathrm{DMPA}$ was found in only small amounts.

In rice (Table 2), similar to the case of azuki bean, absorbed ${ }^{14} \mathrm{C}-\mathrm{CMP}$ and ${ }^{14} \mathrm{C}$ DMPA were rapidly converted in both plant

Table 6. Metabolites in water-soluble fractions derived from root applied ${ }^{14} \mathrm{C}-\mathrm{CMP}$ and ${ }^{14} \mathrm{C}-\mathrm{DMPA}$ in azuki bean seedlings (after $\mathrm{HCl}$ acid hydrolysis).

\begin{tabular}{|c|c|c|c|c|c|c|c|c|}
\hline \multirow{3}{*}{$\begin{array}{l}\text { Plants } \\
\text { Parts }\end{array}$} & \multirow{3}{*}{$\begin{array}{c}\text { Compounds } \\
\text { treated }\end{array}$} & \multirow{3}{*}{$\mathrm{DAA}^{2)}$} & \multicolumn{6}{|c|}{ Radioactivity (\%) ${ }^{1)}$} \\
\hline & & & \multicolumn{5}{|c|}{ Re-extracted $\mathrm{CH}_{2} \mathrm{Cl}_{2}$-soluble fraction } & \multirow{2}{*}{$\begin{array}{l}\text { Water-4) } \\
\text { soluble } \\
\text { fraction }\end{array}$} \\
\hline & & & DMPA & $\begin{array}{c}3-\mathrm{CH}_{2} \mathrm{OH} \\
-\mathrm{DMPA} \\
\end{array}$ & $\begin{array}{l}\text { 5-OH- } \\
\text { DMPA }\end{array}$ & $\mathrm{UK}^{3)}$ & Origin & \\
\hline \multirow{6}{*}{ Root } & \multirow{3}{*}{${ }^{14} \mathrm{C}-\mathrm{CMP}$} & 0 & 0.69 & 0.83 & 0.03 & 0.12 & 0.05 & 1.48 \\
\hline & & 1 & 4.71 & 2.91 & 0.09 & 0.21 & 0.13 & 4.45 \\
\hline & & 3 & 31.76 & 9.88 & 0.37 & 2.08 & 0.80 & 11.51 \\
\hline & \multirow{3}{*}{${ }^{14} \mathrm{C}-\mathrm{DMPA}$} & 0 & 13.98 & 19.54 & 0.74 & 2.38 & 1.31 & 32.45 \\
\hline & & 1 & 15.64 & 26.26 & 0.90 & 3.39 & 1.37 & 36.62 \\
\hline & & 3 & 17.85 & 28.74 & 1.04 & 2.98 & 1.73 & 33.46 \\
\hline \multirow{6}{*}{ Shoot } & \multirow{3}{*}{${ }^{14} \mathrm{C}-\mathrm{CMP}$} & 0 & 1.53 & 11.13 & 0.34 & 0.76 & 0.40 & 17.74 \\
\hline & & 1 & 3.22 & 17.29 & 0.66 & 0.94 & 0.58 & 31.21 \\
\hline & & 3 & 4.55 & 25.08 & 0.87 & 1.98 & 0.74 & 32.18 \\
\hline & \multirow{3}{*}{${ }^{14} \mathrm{C}-\mathrm{DMPA}$} & 0 & 2.31 & 33.89 & 0.99 & 2.75 & 1.47 & 49.59 \\
\hline & & 1 & 2.36 & 38.78 & 1.13 & 1.42 & 0.62 & 51.39 \\
\hline & & 3 & 2.75 & 42.90 & 1.33 & 2.70 & 1.17 & 44.55 \\
\hline
\end{tabular}

1) based on total radioactivity in either roots or shoots

2) DAA : days after application

3 ) consists of several unidentified metabolites

4 ) water-soluble fraction after hydrolysis 
parts. CMP was decreased to 14.69 and 11.5 $\%$ in root and shoot, respectively, within 3 days and metabolite DMPA was found in amounts of 6.04 and $4.52 \%$ in root and shoot, which were larger than those in azuki bean. When ${ }^{14} \mathrm{C}$-DMPA was used as the initial compound, DMPA was metabolized rapidly, and less than $2 \%$ remained in both plant parts 3 days after application.

In tomato and radish, ${ }^{14} \mathrm{C}-\mathrm{CMP}$ and ${ }^{14} \mathrm{C}-$ DMPA were metabolized more slowly than in azuki bean and rice (Table 3 and 4).

In tomato 3 days after application, percents of CMP were 69.75 and $20.65 \%$, and of metabolite DMPA were 2.69 and $4.16 \%$, respectively, in roots and shoots. Three days after application of ${ }^{14} \mathrm{C}$-DMPA, the parent DMPA remained 4.88 and $5.63 \%$ in root and shoot. In radish, percents of CMP and metabolite DMPA were found much higher than other species (CMP : 87.7\% and $48.9 \%$ in roots and shoots, and DMPA : respectively $1.81 \%$ and $10.82 \%$ ). The amount of parent DMPA applied as ${ }^{14} \mathrm{C}$-DMPA was also high in both parts $(5.04$ and $7.26 \%$ in roots and shoots, respectively).

In shoots of plants treated with ${ }^{14} \mathrm{C}-\mathrm{CMP}$, high concentration of the parent CMP remained in all plant species, but the amount of metabolite DMPA found was rather small, especially in azuki bean (Table 5). With ${ }^{14} \mathrm{C}-$ DMPA treatment, it was found that DMPA in shoot of azuki bean and rice was metabolized more rapidly than those in tomato and radish. It might be concluded that in all species, CMP was metabolized to a phytotoxic DMPA, and DMPA was detoxified to non-phytotoxic metabolites. The rapid detoxification of DMPA in both azuki bean and rice may be the reason these species are tolerant to this herbicide. In contrast, in tomato and radish, although the conversion of CMP to DMPA was rather fast, the metabolism of DMPA was quite slow ; this may explain the susceptibility of the plants.

These results are similar to the report that ${ }^{14} \mathrm{C}-\mathrm{CMP}$ was rapidly metabolized to DMPA, $3-\mathrm{CH}_{2} \mathrm{OH}-\mathrm{DMPA}$, water-soluble and insol-

Table 7. Metabolites in water-soluble fractions derived from root applied ${ }^{14} \mathrm{C}$-CMP and ${ }^{14} \mathrm{C}-\mathrm{DMPA}$ in rice seedlings (after $\mathrm{HCl}$ acid hydrolysis).

\begin{tabular}{|c|c|c|c|c|c|c|c|c|}
\hline \multirow{3}{*}{$\begin{array}{l}\text { Plants } \\
\text { parts }\end{array}$} & \multirow{3}{*}{$\begin{array}{c}\text { Compounds } \\
\text { treated }\end{array}$} & \multirow{3}{*}{$\mathrm{DAA}^{2)}$} & \multicolumn{6}{|c|}{ Radioactivity (\%) ${ }^{1)}$} \\
\hline & & & \multicolumn{5}{|c|}{ Re-extracted $\mathrm{CH}_{2} \mathrm{Cl}_{2}$-soluble fraction } & \multirow{2}{*}{\begin{tabular}{|l|} 
Water-4) \\
soluble \\
fraction
\end{tabular}} \\
\hline & & & DMPA & $\begin{array}{c}\text { 3- } \mathrm{CH}_{2} \mathrm{OH} \\
\text {-DMPA } \\
\end{array}$ & $\begin{array}{l}\text { 5-OH- } \\
\text { DMPA }\end{array}$ & $\mathrm{UK}^{3)}$ & Origin & \\
\hline \multirow{7}{*}{ Root } & \multirow{4}{*}{${ }^{14} \mathrm{C}-\mathrm{CMP}$} & 0 & 0.81 & 2.25 & 0.07 & 0.41 & 0.06 & 2.12 \\
\hline & & 1 & 3.01 & 7.70 & 0.25 & 1.45 & 0.28 & 5.55 \\
\hline & & 3 & 8.81 & 16.94 & 0.69 & 4.32 & 0.72 & 27.11 \\
\hline & & & & & & & & \\
\hline & \multirow{3}{*}{${ }^{14} \mathrm{C}-\mathrm{DMPA}$} & 0 & 11.33 & 16.41 & 0.97 & 5.43 & 1.61 & 20.00 \\
\hline & & 1 & 10.94 & 17.80 & 0.68 & 4.30 & 4.00 & 24.93 \\
\hline & & 3 & 10.50 & 19.57 & 1.43 & 6.21 & 2.07 & 24.26 \\
\hline \multirow{7}{*}{ Shoot } & \multirow{4}{*}{${ }^{14} \mathrm{C}-\mathrm{CMP}$} & 0 & 2.49 & 7.17 & 0.16 & 0.69 & 0.07 & 4.06 \\
\hline & & 1 & 3.31 & 13.15 & 0.65 & 1.92 & 0.08 & 17.39 \\
\hline & & 3 & 4.88 & 24.21 & 0.72 & 4.22 & 0.31 & 29.18 \\
\hline & & & & & & & & \\
\hline & \multirow{3}{*}{${ }^{14} \mathrm{C}-\mathrm{DMPA}$} & 0 & 10.47 & 21.68 & 0.46 & 3.02 & 0.39 & 18.60 \\
\hline & & 1 & 9.36 & 23.97 & 0.62 & 2.34 & 0.26 & 31.61 \\
\hline & & 3 & 8.87 & 28.96 & 0.80 & 2.85 & 0.38 & 27.00 \\
\hline
\end{tabular}

1) based on total radioactivity in either roots or shoots

2) DAA : days after application

3 ) consists of several unidentified metabolites

4 ) water-soluble fraction after hydrolysis 
Table 8. Metabolites in water-soluble fraction derived from root applied ${ }^{14} \mathrm{C}$-CMP and ${ }^{14} \mathrm{C}-\mathrm{DMPA}$ in tomato and radish seedlings at 3 days after application (after $\mathrm{HCl}$ acid hydrolysis).

\begin{tabular}{|c|c|c|c|c|c|c|c|}
\hline \multirow{3}{*}{$\begin{array}{l}\text { Plant } \\
\text { parts }\end{array}$} & \multirow{3}{*}{$\underset{\text { treated }}{{ }^{14} \mathrm{C}}$} & \multicolumn{6}{|c|}{ Radioactivioy (\%) } \\
\hline & & \multicolumn{5}{|c|}{ Re-extracted $\mathrm{CH}_{2} \mathrm{Cl}_{2}$-soluble fraction } & \multirow{2}{*}{$\begin{array}{l}\text { Water-3) } \\
\text { soluble } \\
\text { fraction }\end{array}$} \\
\hline & & DMPA & $\begin{array}{l}\text { 3- } \mathrm{CH}_{2} \mathrm{OH} \\
\text {-DMPA }\end{array}$ & $\begin{array}{l}\text { 5-OH- } \\
\text { DMPA }\end{array}$ & $\mathrm{UK}^{2)}$ & Origin & \\
\hline Tomato & CMP & 7.14 & 3.58 & - & 0.62 & 0.17 & 5.38 \\
\hline Root & DMPA & 47.65 & 8.27 & - & 2.24 & 0.50 & 14.05 \\
\hline \multirow{2}{*}{ Shoot } & CMP & 18.07 & 20.16 & - & 2.02 & 0.47 & 18.94 \\
\hline & DMPA & 40.79 & 20.31 & - & 1.29 & 0.17 & 21.49 \\
\hline$\underline{\text { Radish }}$ & CMP & 1.59 & 0.38 & 0.02 & 0.17 & 0.05 & 1.30 \\
\hline Root & DMPA & 12.77 & 21.69 & 0.57 & 2.17 & 0.62 & 20.12 \\
\hline \multirow[t]{2}{*}{ Shoot } & CMP & 2.74 & 8.35 & 0.53 & 1.26 & 0.03 & 10.81 \\
\hline & DMPA & 11.98 & 31.81 & 0.76 & 1.25 & 0.39 & 22.48 \\
\hline
\end{tabular}

1) based on total radioactivity in either roots or shoots

2) consists of several unidentified metabolites

3 ) water-soluble fraction after hydrolysis

uble metabolites in shoot and rhizome of Cyperus serotinus studied by KOBAYASHI et $a l^{1)}$.

In root, although the remainder of both CMP and DMPA was rather high (because a large amount of absorbed herbicide was still in the root), no toxic symptom of roots was clearly exhibited.

In order to study the detoxification pathway, metabolites in water-soluble fractions were identified. After hydrolyzation, the main compounds in dichloromethane-soluble fractions were $3-\mathrm{CH}_{2} \mathrm{OH}-\mathrm{DMPA}$ and DMPA in all 4 species of plants (Table 6, 7 and 8 ) : and $3-\mathrm{CH}_{2} \mathrm{OH}-\mathrm{DMPA}$ was found in more quantity than DMPA.

From these results, it might be concluded that CMP in plants was hydrolyzed at the acylamide bond and resulted in DMPA (the herbicidal active compound). In order to detoxify DMPA, a methyl group in the pheny1 ring of DMPA might be hydroxylated resulting in $3-\mathrm{CH}_{2} \mathrm{OH}-\mathrm{DMPA}$. Both DMPA and $3-\mathrm{CH}_{2} \mathrm{OH}-\mathrm{DMPA}$ could be conjugated with plant metabolites and transferred to water-soluble fraction. The conversion rates of CMP to DMPA and then to water-soluble metabolites were different among plant species, and governed the tolerance or suscep- tibility to this herbicide.

\section{Summary}

Azuki bean, rice, tomato and radish were able to metabolize CMP to non-phytotoxic metabolites, but the conversion rates differed among plant species. Azuki bean and rice effectively metabolized CMP and DMPA to water-soluble and acetone/water-insoluble metabolites, whereas in tomato and radish the metabolism rates were much slower, especially at the step of the conversion of DMPA to non-phytotoxic metabolites. The tolerance of azuki bean and rice and the susceptibility of tomato and radish to the herbicides might be explained by the different metabolism rates.

The hydrolization at the acylamide bond of CMP resulted in DMPA (the herbicidal active compound) and the hydroxylation of methyl group in the phenyl ring resulted in 3$\mathrm{CH}_{2} \mathrm{OH}$-DMPA. Thus the conjugations of both DMPA and 3- $\mathrm{CH}_{2} \mathrm{OH}-\mathrm{DMPA}$ with plant metabolites are the probable pathways of metabolism of CMP in these plant species.

Acknowledgement : The authors would like to express their appreciation to Mitsubishi Petrochemical Co., Ltd. for supplying the ${ }^{14} \mathrm{C}$ 
compounds used in this study.

\section{References}

1) KoBAyASHI, K., K. ICHINOSE and $\mathrm{H}$. SUGIYAMA (1988): Absorption, translocation and metabolism of clomeprop in Cyperus serotinus. Weed Res., Japan 33 (Suppl.), 133134 (in Japanese).

2 ) OYamada, M., T. TANAKa, Y. TAKASAWA and T. TAKEMATSU (1986): Metabolic fate of herbicide naproanilide in rice plants (Oryza sativa L.) and Sagittaria pygmaea MIG. J. Pestic. Sci. 11, 197-203.

3 ) SHIRAKURA, S., K. ISHIZUKA, Y. IKEDA and K. KONNO (1986) : Mode of action of selectivity of clomeprop (MY-15). Weed Res.,
Japan 31 (Suppl.), 150-151 (in Japanese).

4 ) SugAyA, K., Y. IKedA, A. Go, K. Konno and M. TANAKA (1986) : Activity of clomeprop (MY-15), the paddy field herbicide. Weed Res., Japan 31 (Suppl.) , 149-150 (in Japanese).

5 ) TAKASAWA, Y., T. TANAKA, M. OYAMADA, K. IGARASHI and T. YoshIMOTO (1982): Selective activity of 2- (2-naphthoxy) propionanilide (Naproanilide). Proc. $5^{\text {th }}$ Int. Congr. Pestic. Chem., IV d-10.

6 ) WongwattanA, C. and K. IshizukA (1988) : Herbicidal activity, absorption and translocation of clomeprop in plant seedlings. Weed Res., Japan 33(3), 191 199.

(Received August 24, 1988)

\section{各種植物体におけるクロメプロップの代謝}

$$
\text { チャレムチャイウウンワッタナ・石塚皓造 筑波大応用生化 }
$$

クロメプロップとその酸アミド結合加水分解代謝物 (それぞれ CMP と DMPA と略称) のアズキとイネ (抵 抗性）およびトマトとダイコン（感受性）幼植物体中代謝を調べた。 ${ }^{14} \mathrm{C}$ 標識 CMP と DMPA とを用い，24時 間根部より吸収させた後経日的に試料を採取した。ジクロロメタン可溶画分，水可溶面分およびアセトン／水 不溶画分に夫々分画し，加水分解反応と TLC 等を組み合わせて定性定量を行った(第 1 図)。4 植物種とも親 化合物を代謝し，代謝産物の種類には差異は認められなかったが，代謝速度に植物種間差が認められた(第 1 $\sim 4$ 表)。

CMP および DMPA から殺草活性の無い化合物への变化の速度は，アズキおよびイネ体内ではトマトおよ びダイコンに比べて著しく大であった (第 5 表，第 $2 ， 3$ 図)。特にDMPA の体内保留濃度がアズキとイネ では著しく小であった（第 5 表，第 $2 ， 3$ 図)。CMP の代謝産物として，DMPAの他にフェニール環側鎖の メチル基が水酸化された化合物 (3- $\mathrm{CH}_{2} \mathrm{OH}-\mathrm{DMPA}$ )が見出された。DMPA および3- $\mathrm{CH}_{2} \mathrm{OH}-\mathrm{DMPA}$ の抱合 物が主たる解毒物質として同定された (第 $6,7,8$ 表)。 